\title{
Cobalamins and nitrous oxide: a review
}

\author{
I CHANARIN
}

From the Department of Haematology, MRC Clinical Research Centre, Harrow, Middlesex, UK

The anaesthetic gas, nitrous oxide $\left(\mathrm{N}_{2} \mathrm{O}\right)$, once regarded as chemically inert, oxidises some forms of vitamin $B_{12}$. It does this both when used clinically and in the test tube, and the action is remarkably selective. As far as we know, no other pathway or substance is affected except as a result of damage to vitamin $\mathbf{B}_{12}$. Vitamin $\mathbf{B}_{12}$ that has been oxidised in this way no longer functions as a coenzyme. Thus the effect of $\mathrm{N}_{2} \mathrm{O}$ presents the biochemist and haematologist with a remarkable tool with which to explore the mode of action of vitamin $B_{12}$. It presents the neurologist and neuropathologist with a new probe into the mechanism of vitamin $\mathbf{B}_{12}$ neuropathy, and finally it is a new tool with which to explore the complex field of vitamin $\mathrm{B}_{12}$-folate interrelations.

The purpose of this review is to discuss current work in these fields. No attempt is made to discuss $\mathrm{N}_{2} \mathrm{O}$ from the viewpoint of an anaesthetic agent, and the review deals only with the effect on vitamin $B_{12}$.

\section{Chemistry}

In vitro a relationship between vitamin $\mathrm{B}_{12}$ and $\mathrm{N}_{2} \mathrm{O}$ was demonstrated by Banks et al. ${ }^{1}$ and others. ${ }^{2}$ Vitamin $B_{12}$ is one of a group of transition-metal complexes having a metallic ion linked directly to an organic compound. These are able to activate $\mathrm{N}_{2} \mathrm{O}$, releasing free nitrogen and oxygen. The $\mathrm{B}_{12}$ itself is changed rapidly from the reduced cob(I)alamin or $B_{12 s}$ form to the oxidised cob(III)alamin or $\mathbf{B}_{12 \mathrm{a}}$ form, a change accompanied by rapid conversion of the grey-green colour of cob(I)alamin to a reddish-brown colour due to a mixture of cob(II) and cob(III)alamin. The latter is inactive in such pathways as methionine synthetase, which require cobalt in the fully reduced state.

$\mathrm{Cob}(\mathrm{I})$ alamin $+\mathrm{N}_{2} \mathrm{O} \rightarrow \mathrm{Cob}(\mathrm{III})$ alamin $+\mathrm{H}_{2} \mathrm{O}+\mathrm{N}_{2}$ $\mathrm{Cob}($ III)alamin $+\operatorname{cob}($ I)alamin $\rightarrow 2$ cob(II)alamin

In the intact animal it is likely that the enzyme as well as the coenzyme $\left(B_{12}\right)$ is damaged, presumably secondary to damage to the $B_{12}$, because recovery from $\mathrm{N}_{2} \mathrm{O}$ exposure takes several days, and recovery

Received for publication 31 March 1980 is not more rapid if $\mathbf{B}_{12}$ is supplied, suggesting that new apoenzyme needs to be synthesised.

\section{Clinical observations}

The first clinical report of toxicity that could be ascribed to $\mathrm{N}_{2} \mathrm{O}$ was that of Lassen et al. in $1956,{ }^{3}$ who used a $50 \% \mathrm{~N}_{2} \mathrm{O} /$ oxygen mixture as well as other agents to control the spasms in patients with tetanus. Treatment was continued for up to six days. Two of the patients died, and pancytopenias appeared in most of the patients accompanied by megaloblastic haemopoiesis demonstrated by marrow aspiration. The marrow, indeed, was indistinguishable from that in untreated pernicious anaemia. A similar experience was reported in a further case from Australia. ${ }^{4}$

Amess et al.,5 in studying the effects of $\mathrm{N}_{2} \mathrm{O}$ during and after open heart surgery, found that the marrow was megaloblastic and, by use of the deoxyuridine suppression test, they showed that the pattern of behaviour was similar to that of marrow in untreated pernicious anaemia where there is some return towards normality in the test by the addition of vitamin $B_{12}$. There was a greater improvement on the addition of folate.

At about the same time reports of a neuropathy in those exposed to excess amounts of $\mathrm{N}_{2} \mathrm{O}$ began to appear in the medical literature. By far the largest group were dentists who had developed some addiction to $\mathrm{N}_{2} \mathrm{O}$ inhalation, but a dentist and his assistant, who were exposed to $\mathrm{N}_{2} \mathrm{O}$ from a leak in defective anaesthetic equipment, were both affected, as was a young lady who obtained her $\mathrm{N}_{2} \mathrm{O}$ from capsules designed to produce whipped cream in the home. ${ }^{6-9}$

The commonest early symptom was numbness and tingling in the hands or feet. A few noticed loss of dexterity of the fingers, poor balance, or leg weakness. One patient first noticed continuous twitching of two toes on one foot. At first the numbness tended to be patchy but symmetrical. Eventually numbness of the legs was present in all the patients, and in most the hands were also affected. Many became unsteady because of sensory loss and about half were unable to walk unassisted. Neck flexion produced a shock sensation radiating down to the legs or, in one case, 
the arms (Lhermitte sign). Impotence, difficulty with micturition, and constipation were common. Half the patients were depressed with impaired memory and had difficulty in thinking clearly. Ten out of 15 patients had to stop work as a result of their neuropathy. ${ }^{6}$

Examination in the early stages showed only reduced knee and ankle jerks and slight loss of touch and vibration sense in the extremities. Subsequently, the tendon reflexes became brisk with a positive Babinski sign. This was accompanied by severe loss of sensation affecting limbs and trunk, positive Romberg sign, and a wide-based ataxic gait.

Electromyography showed denervation, and motor nerve conduction tests reduced conduction velocity in all patients tested. Sensory nerve testing showed a reduced amplitude or increased latency of evoked potentials in five out of six cases.

Examination of cerebrospinal fluid was generally normal (one patient had increased protein). The serum vitamin $\mathbf{B}_{12}$ level was normal in seven cases but was 170 and $185 \mathrm{pg} / \mathrm{ml}$ in two others. Absorption of vitamin $B_{12}$ was normal. One patient had hypersegmented neutrophils in the blood film.

A large survey has been carried out in the USA among dentists who use $\mathrm{N}_{2} \mathrm{O}$ for anaesthesia as compared to those who do not. In male dentists using $\mathrm{N}_{2} \mathrm{O}$ there was a $75 \%$ increase in liver disease, a $70 \%$ increase in neurological disease, and a $55 \%$ increase in spontaneous abortion in their wives as compared to the control group. ${ }^{10}$ Among female dental assistants exposed to $\mathrm{N}_{2} \mathrm{O}$ there was, in addition, a $155 \%$ increase in the abortion rate, an $80 \%$ increase in congenital malformations, and even a $90 \%$ increase in cancer as compared to controls.

These reports have stimulated considerable interest and even some activity. An understanding of the effect of $\mathrm{N}_{2} \mathrm{O}$ may be important for several reasons:

$1 \mathrm{~N}_{2} \mathrm{O}$, if it could be used safely, is a valuable and potent analgesic, particularly in severely injured patients, after major surgery, and in child birth. Is there some way in which the toxic effects of prolonged use can be prevented?

2 What are the consequences of exposure to low levels of $\mathrm{N}_{2} \mathrm{O}$ over relatively long periods of time, as may occur among staff working in operating theatres in both general surgery and dentistry?

3 What are the biochemical consequences of $B_{12}$ inactivation in man and the experimental animal, and does it offer a model in which to study the effects of $B_{12}$ deficiency, including the changes in the nervous system and the effects on folate metabolism?

4 Are the analgesic and para-anaesthetic effects influenced by the same or different pathways from those that affect $B_{12}$ ?

\section{General remarks}

Vitamin $\mathbf{B}_{12}$ functions as a coenzyme. Ten enzymatic reactions have been identified requiring adenosylcobalamin but only one, methylmalonylCoA mutase, occurs in mammals including man.11 Several reactions require a second $B_{12}$ analogue, methylcobalamin, but only one of these pathways, methionine synthetase, has been found in mammals. Either independently of these reactions, or through their agency, vitamin $B_{12}$ is necessary for the normal functioning of the folate coenzymes. Thus $\mathrm{N}_{2} \mathrm{O}$ affects not only the $B_{12}$ coenzymes but also the folate coenzymes.

Diseases due to $B_{12}$ deficiency occur in man and in ruminants grazed on cobalt-deficient pastures. Neither has proved to be an ideal model for study, man because therapy rapidly reverses the picture and because, for ethical reasons, tissues such as liver are not normally available, and ruminants because their size makes them too awkward to manage, although valuable studies have been carried out on sheep in Australia. ${ }^{12}$ Dietary depletion can produce partial $\mathrm{B}_{12}$ deficiency in rats, and a clean fruit diet leads to $B_{12}$ neuropathy in fruit bats. ${ }^{14}$ Man alone, however, develops a megaloblastic anaemia after $B_{12}$ deficiency, and ultimately we will have to look to human data to resolve this problem.

At the time of writing, the effects of $\mathrm{N}_{2} \mathrm{O}$ are being studied to a variable extent in man, monkey, rat, mouse, fruit bat, and some bacteria.

EFFECTS OF $\mathrm{N}_{2} \mathrm{O}$ ON VITAMIN B12 MEDIATED PATHWAYS

\section{Methionine synthetase}

In this reaction homocysteine takes up a methyl group to form methionine. The source of the methyl is usually either the $\beta$-carbon of serine or the $\alpha$-carbon of glycine. The carbon unit is taken up by folate to form 5,10-methylenetetrahydropteroylpentaglutamate. Thereafter the methylene $\left(-\mathrm{CH}_{2}-\right)$ is reduced to methyl $\left(\mathrm{CH}_{3}-\right)$ to give 5-methyltetrahydropteroylpentaglutamate, the methyl is then transferred to cob(I)alamin to give methylcobalamin, and this is the final methyl donor.

Direct assay of enzyme activity in the liver of Sprague-Dawley rats exposed to a $50 \% \mathrm{~N}_{2} \mathrm{O}$ /oxygen mixture showed a substantial fall after $\mathbf{3 0}$ minutes' exposure, and after 6 hours methionine synthetase activity was at a virtually zero level.15 16 The levels remain virtually undetectable for as long as exposure to $\mathrm{N}_{2} \mathrm{O}$ is continued, this particular study being terminated after 15 days. Recovery of activity after withdrawal of $\mathrm{N}_{2} \mathrm{O}$ is relatively slow, there being a steady restoration over not less than four days. 
Brain methionine synthetase is depressed to an equal degree, and this too persists throughout the period of exposure to $\mathrm{N}_{2} \mathrm{O} .{ }^{17}$ There is no accompanying homocysteinuria. Kondo et al..$^{18}$ preceded exposure to $\mathrm{N}_{2} \mathrm{O}$ with an injection of ${ }^{57} \mathrm{Co}-\mathrm{B}_{12}$. Chromatography was used to separate labelled $\mathrm{B}_{12}$ on the hepatic mutase and synthetase. With $\mathrm{N}_{2} \mathrm{O}$ exposure there was a steady fall in labelled $\mathrm{B}_{12}$ in the position of methionine synthetase.

The long recovery period after withdrawal of $\mathrm{N}_{2} \mathrm{O}$ suggests that the apoenzyme is degraded after loss of $\mathbf{B}_{12}$, and the delay in recovery is due to synthesis of new apoenzymes.

\section{Methylmalonyl-CoA-mutase}

The conversion of methylmalonic acid (MMA) to succinic acid requires adenosylcobalamin as coenzyme. MMA arises from metabolism of propionic acid, valine, leucine, and isoleucine. It may be excreted in the urine in $B_{12}$ deficiency, particularly if a precursor substance has been given. MMA was not detected other than in trace amounts in the urine of rats exposed to $\mathrm{N}_{2} \mathrm{O}$ even after an injection of propionic acid, whereas a group of rats on a $B_{12}$-deficient diet increased their excretion from $0.1 \mathrm{mg}$ to $36 \mathrm{mg}$ in 24 hours. ${ }^{15}$ It was concluded that the form of $\mathrm{B}_{12}$ in this reaction was not susceptible to the oxidative action of $\mathrm{N}_{2} \mathrm{O}$. This could be because the reaction did not require a reduced cobalamin. Although methionine synthetase is a cytosol enzyme and the mutase a mitochondrial one, this is probably not a likely explanation for the difference in behaviour as $\mathrm{N}_{2} \mathrm{O}$ readily penetrates cell organelles such as mitochondria. Kondo et al. ${ }^{18}$ confirmed that in liver from an animal given ${ }^{57} \mathrm{Co}-\mathrm{B}_{12}$ the radioactivity on the mutase remained intact, unlike that on the synthetase. A report that there is an increased excretion of MMA in mice receiving $80 \% \mathrm{~N}_{2} \mathrm{O}$ has been withdrawn. ${ }^{19}$

\section{Vitamin $B_{12}$ coenzyme levels}

The loss of methylcobalamin in rat liver and the maintenance of $\mathrm{B}_{12}$ on the mutase, presumably adenosylcobalamin, demonstrated by Kondo et al. ${ }^{18}$ has been mentioned. Patients developing neuropathy due to $\mathrm{N}_{2} \mathrm{O}$ inhalation generally have normal serum B $_{12}$ levels. ${ }^{7}$ Linnell et al. ${ }^{20}$ exposed human lymphocytes, which had been incubated with phytohaemagglutinin and ${ }^{57} \mathrm{Co}-\mathrm{B}_{12}$ for 72 hours, to 60 seconds' $\mathrm{N}_{2} \mathrm{O}$. This was followed by a decline in the amount of methylcobalamin in the cell while the level of adenosylcobalamin was maintained.

\section{Ethanolamine ammonia-lyase}

This clostridial enzyme converts ethanolamine to acetaldehyde. It too is inactivated by exposure to
$\mathrm{N}_{2} \mathrm{O}$, implying a reduced cobalt derivative in the adenosylcobalamin. ${ }^{21}$ It does not occur in mammals.

\section{EFFECTS OF N2O ON FOLATE AND FOLATE COENZYMES}

\section{Hepatic uptake of injected folate}

Using mice, McGing et al. ${ }^{22}$ showed that ${ }^{3} \mathrm{H}$-labelled pteroylglutamic acid ( $\left.{ }^{3} \mathrm{H}-\mathrm{PteGlu}\right)$, given intraperitoneally, was taken up poorly by liver after $\mathrm{N}_{2} \mathrm{O}$ inhalation. The uptake after $\mathrm{N}_{2} \mathrm{O}$ was reduced to only $40 \%$ of the amount taken up by controls. The hepatic uptake of physiological folate analogues is also impaired after $\mathrm{N}_{2} \mathrm{O}$ inhalation. ${ }^{23}$ The results in Table 1 show that $21 \%$ of tetrahydropteroylglutamic acid $\left(\mathrm{H}_{4}\right.$ PteGlu) was taken up by liver as compared to the uptake in a control animal. The normal transport form of folate is 5-methyltetrahydrofolic acid (5- $\left.\mathrm{CH}_{3}-\mathrm{H}_{4} \mathrm{PteGlu}\right)$ and, following $\mathrm{N}_{2} \mathrm{O}$, its hepatic uptake was reduced to $38 \%$ of the uptake in an untreated animal. The formylfolates are less affected, values ranging from 56 to $69 \%$ of that in controls.

Table 1 Uptake of labelled folate analogues, given intraperitoneally to rats, by liver and their conversion into folatepolyglutamate ${ }^{23}$

\begin{tabular}{|c|c|c|c|c|c|}
\hline \multirow{2}{*}{$\begin{array}{l}\text { Folate IP } \\
0.01 \mathrm{\mu mol}\end{array}$} & \multicolumn{3}{|c|}{$\%$ IP folate in liver } & \multicolumn{2}{|c|}{$\begin{array}{l}\% \text { IP folate as } \\
\text { polyglutamate }\end{array}$} \\
\hline & Control & $\begin{array}{l}\mathrm{N}_{2} \mathrm{O}- \\
\text { treated }\end{array}$ & $\mathrm{C} / \mathrm{N}_{2} \mathrm{O} \%$ & Control & Treated \\
\hline $\begin{array}{l}\mathrm{H}_{4} \mathrm{PteGlu} \\
5 \mathrm{CH}_{3} \mathrm{H}_{4} \text { PteGlu } \\
5 \mathrm{CHOH}, \mathrm{PteGlu}_{3} \\
10 \mathrm{CHOH} \mathrm{HteGlu}_{4} \\
5,10 \mathrm{CHH}_{4} \text { PteGlu }\end{array}$ & $\begin{array}{l}3 \cdot 7 \\
4 \cdot 2 \\
5 \cdot 3 \\
6 \cdot 7 \\
5 \cdot 06\end{array}$ & $\begin{array}{l}0 \cdot 78 \\
1 \cdot 6 \\
2 \cdot 96 \\
4 \cdot 63 \\
3 \cdot 47\end{array}$ & $\begin{array}{l}(21) \\
(38) \\
(56) \\
(69) \\
(69)\end{array}$ & $\begin{array}{l}55 \\
42 \\
52 \\
52 \\
55\end{array}$ & $\begin{array}{r}0 \\
0 \\
49 \\
46 \\
59\end{array}$ \\
\hline
\end{tabular}

\section{Synthesis of folatepolyglutamate}

The active form of folate functioning as a coenzyme is a polyglutamate, that is, it has additional glutamic acid residues, usually four, to form a pentaglutamate. The glutamic acid peptide chain serves to attach the coenzyme to the apoenzyme. The enzyme adding on glutamic acid units, folatepolyglutamate synthetase or ligase, is present in all cells. After $\mathrm{N}_{2} \mathrm{O}$ McGing et al..$^{22}$ found a decline in polyglutamate formation in the livers of mice given the oxidised PteGlu, and the results in rats, again with physiological analogues, are shown in Table 1. There was no detectable polyglutamate formation with either $\mathrm{H}_{4} \mathrm{PteGlu}$ or $5-\mathrm{CH}_{3}-\mathrm{H}_{4} \mathrm{PteGlu}$ as substrates. However, folate polyglutamate formation was entirely normal when formyltetrahydrofolate $\left(\mathrm{CHO}-\mathrm{H}_{4} \mathrm{PteGlu}\right)$ was given.

The data indicate that polyglutamate formation itself is unaffected by inactivation of $B_{12}$, and the 
results imply that $\mathbf{B}_{12}$ is concerned in the provision of the correct substrate for polyglutamate synthesis. The data further imply that the correct substrate is formyltetrahydrofolate. By implication $\mathbf{B}_{12}$ is concerned in this formylation step.

Serum folate levels

The serum folate level is usually normal in untreated pernicious anaemia, but in some patients the serum level is increased. After $\mathrm{N}_{2} \mathrm{O}$ inhalation in rats Lumb et al. (unpublished observations) found a very marked increase in serum folate level within several hours of exposure, and this level remained elevated while $\mathrm{N}_{2} \mathrm{O}$ inhalation was continued. 5-Methyltetrahydrofolate undergoes an enterohepatic circulation, and the rise in serum methylfolate level appears to be due to interruption of the enterohepatic cycle by the impaired uptake of the methylfolate by liver (see Table 1).

\section{Liver folate}

The liver is a major site of folate metabolism and holds half or more of the folate in the body. The amount and form of folate in liver following $\mathrm{N}_{2} \mathrm{O}$ was of interest because it provided an opportunity for testing the 'methylfolate trap hypothesis' ${ }^{24} 25$ This hypothesis states that failure of the methionine synthetase reaction, in which the methyl group of methylfolate is transferred to homocysteine, leads to an accumulation of methylfolate and hence to lack of other folate analogues. Elevation of serum folate may occur in untreated pernicious anaemia and favours the concept of accumulation of methylfolate but the red cell folate is reduced in two-thirds of patients so that there is no pile-up of methylfolate at this site. It has proved ethically impossible to obtain pretreatment tissues from other sites, such as liver biopsy material, in untreated pernicious anaemia to test the hypothesis further.

Inactivation of the methionine synthetase path by $\mathrm{N}_{2} \mathrm{O}$ offered an opportunity to determine if, in fact, methylfolate was trapped or whether it was metabolised by means other than through the homocysteine-methionine reaction.

Figure 1 shows that rats maintained in an atmosphere of $50 \% \mathrm{~N}_{2} \mathrm{O} / 50 \%$ oxygen for 10 days lose folate continuously from the liver. ${ }^{26}$ This loss amounts to $50 \%$ of total folate in the first 48 hours and to $75 \%$ of folate after 10 days. The rate of loss is greatest with folates supporting the growth of Lactobacillus casei (methyltetrahydrofolate as well as other monoglutamate analogues) and is less rapid with Pediococcus cerevisiae-active folates (reduced folate analogues other than methylfolate).

More detailed analysis of methylfolates over the first three days (Fig. 2) shows that there is a rise in

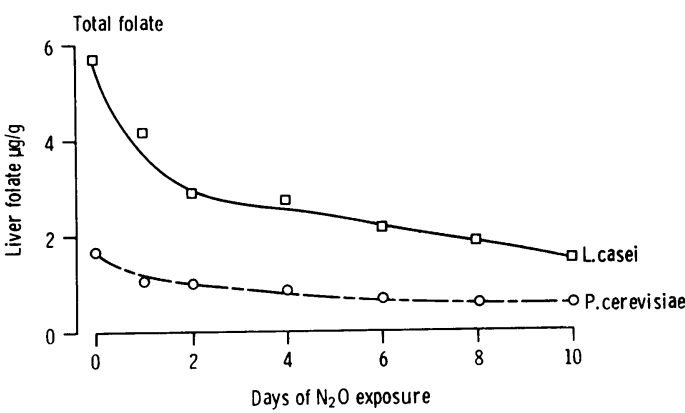

Fig. 1 Rats were maintained in a nitrous oxide/oxygen (1/1) atmosphere for 10 days, carbon dioxide being removed and water vapour monitored. Animals were removed in batches of three, and livers were assayed for folate content by microbiological assay. The marked fall in hepatic folate throughout the period of exposure is shown.

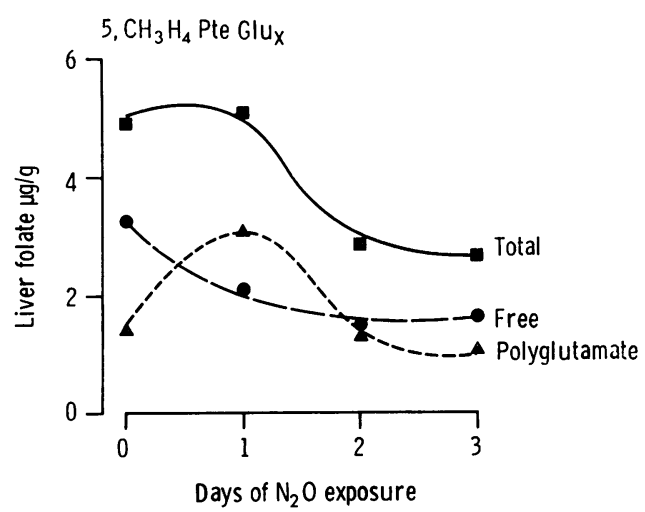

Fig. 2 Experiment as described in the legend to Figure 1. The assay results with P.Fcerevisiae have been subtracted from the values obtained with $\mathrm{L}$. casei. In addition, samples have been assayed before (free folate) and after exposure to conjugase enzyme which removes glutamic acid residues in excess of one from folate polyglutamate. There is a rise in the level of

5-methyltetrahydropteroylpolyglutamate 24 hours after $\mathrm{N}_{2} \mathrm{O}$ exposure but thereafter this declines. There is no transient rise in the free folate level.

5-methyltetrahydropteroylpolyglutamates at 24 hours but no rise of monoglutamates. This rise, however, disappears at 48 hours. The accumulation of methylpolyglutamate is due to cessation of methionine synthetase activity. There is no 'trapping' at the monoglutamate level as postulated in the hypothesis and hence the reaction cannot be concerned with provision of the substrate for folate polyglutamate synthesis. Secondly, the trapping, which not unexpectedly occurs at the polyglutamate or active 
coenzyme level, is transient. At 48 hours the methylpolyglutamate has been metabolised through other pathways, one of which may be the oxidation of the methyl group back to methylene via methylenetetrahydrofolate reductase, a reaction which has been demonstrated in vitro in relation to methylation of biogenic amines. $27-29$

This spectacular fall in hepatic folate is in part due to interruption of the enterohepatic circulation of methyltetrahydrofolate. Liver methylfolate is excreted into bile and thence into small gut where it is reabsorbed and again taken up by the liver. The hepatic uptake of methylfolate after an intraperitoneal injection in an $\mathrm{N}_{2} \mathrm{O}$-treated rat is reduced to onethird of that in control animals. The second factor leading to a fall in hepatic folate after exposure to $\mathrm{N}_{2} \mathrm{O}$ is a virtual cessation of polyglutamate synthesis from methylfolate.

\section{Folate in other tissues}

The change in folate levels in kidney, brain, and marrow after exposure to $\mathrm{N}_{2} \mathrm{O}$ follow the pattern of liver, although the fall in total folate levels is not as great.

\section{Folate catabolism}

The massive loss of folate after $\mathrm{N}_{2} \mathrm{O}$ implies excretion and/or catabolism of folate, but as yet no data have been published.

\section{Utilisation of deoxyuridine by bone marrow}

The utilisation of deoxyuridine for thymidine synthesis, a folate-dependent step, is tested in the deoxyuridine suppression test using bone marrow. 3031 Normal human or rat bone marrow cells will meet more than $90 \%$ of their thymidine requirements by methylation of deoxyuridine (synthetic path), and less than $10 \%$ of ${ }^{3} \mathrm{H}$-thymidine, added to the marrow cell suspension at a later stage, appears in DNA (salvage path). In megaloblastic anaemia there is reduced synthesis of thymidine for DNA synthesis. Thus the uptake of ${ }^{3} \mathrm{H}$-thymidine in megaloblastic anaemia exceeds $10 \%$.

Marrows from patients treated with $\mathrm{N}_{2} \mathrm{O}$ give an abnormal deoxyuridine suppression test, ${ }^{5}$ and in the study of Amess et al. there was a return towards normality on the addition of vitamin $B_{12}$ to the test system. Scott et al. ${ }^{19}$ reported that bone marrow from rats treated with $\mathrm{N}_{2} \mathrm{O}$ developed an abnormal deoxyuridine suppression, which, too, was improved by addition of $\mathrm{B}_{12}$, PteGlu, and $5-\mathrm{CHOH}_{4}$ PteGlu but not by the addition of $5-\mathrm{CH}_{3} \mathrm{H}_{4}$ PteGlu.

A more detailed examination of the role of folate analogues in thymidine synthesis in the $\mathrm{N}_{2} \mathrm{O}$-treated rat was carried out by Deacon et al. ${ }^{16}$ The results (Table 2) were assessed against matched controls, that is, the tubes with ${ }^{3} \mathrm{H}$-thymidine but without deoxyuridine $(=100 \%$ value in the test $)$ also contained whatever other additives had been added to the test mixture. Table 2 shows that the addition of $\mathrm{B}_{12}$ produced no significant improvement, unlike the situation in man and monkey, ${ }^{32}$ and the greatest improvement followed the addition of formyltetrahydrofolates. $\mathrm{H}_{4} \mathrm{PteGlu}$ produced relatively poor improvement in the methylation of deoxyuridine and methylfolate, and PteGlu no improvement. Thus those folate analogues that overcame the block in folate polyglutamate synthesis in the $\mathrm{N}_{2} \mathrm{O}$-treated rat were also the most effective in restoring a more normal deoxyuridine utilisation.

Table 2 Results of the deoxyuridine suppression test with marrow cells in control and $\mathrm{N}_{2} \mathrm{O}$-treated rats and the effect of addition of hydroxocobalamin and/or folate analogues

\begin{tabular}{|c|c|c|c|c|c|c|}
\hline \multirow[t]{2}{*}{ Additive } & \multicolumn{3}{|c|}{ Controls } & \multicolumn{3}{|c|}{$\mathrm{N}_{2} \mathrm{O}$-treated } \\
\hline & No. & Mean & $S D$ & No. & Mean & $S D$ \\
\hline Nil & 40 & $7 \cdot 3$ & $1 \cdot 57$ & 21 & $15 \cdot 7$ & $2 \cdot 46$ \\
\hline $\mathrm{OH}-\mathrm{Cbl}$ & 8 & $6 \cdot 8$ & 1.62 & 8 & $15 \cdot 0$ & $2 \cdot 31$ \\
\hline PteGlu & 4 & 6.7 & $1 \cdot 17$ & 4 & $14 \cdot 7$ & $2 \cdot 13$ \\
\hline $\mathrm{H}_{4}$ PteGlu & 8 & $6 \cdot 5$ & 0.89 & 8 & $12 \cdot 8$ & $2 \cdot 02$ \\
\hline 5-CH ${ }_{3}-\mathrm{H}_{4}$ PteGlu & 8 & $6 \cdot 3$ & $1 \cdot 55$ & 8 & $14 \cdot 5$ & $2 \cdot 86$ \\
\hline 5-CHO-H4PteGlu & 10 & $7 \cdot 5$ & 1.66 & 10 & $9 \cdot 2$ & 1.44 \\
\hline 10-CHO-H 4 PteGlu & 8 & $6 \cdot 2$ & $1 \cdot 22$ & 8 & $9 \cdot 4$ & $1 \cdot 89$ \\
\hline $\mathrm{OH}-\mathrm{Cbl}+$ PteGlu & 4 & $7 \cdot 2$ & $1 \cdot 89$ & 4 & $13 \cdot 8$ & $1 \cdot 55$ \\
\hline $\mathrm{OH}-\mathrm{Cbl}+\mathrm{H}_{4}$ PteGlu & 8 & $7 \cdot \overline{4}$ & $1 \cdot 33$ & 8 & $13 \cdot 5$ & $2 \cdot 90$ \\
\hline $\mathrm{OH}-\mathrm{Cbl}+5-\mathrm{CH}_{3}-\mathrm{H}_{4}$ PteGlu & 8 & 6.6 & $1 \cdot 57$ & 8 & $14 \cdot 1$ & $1 \cdot 56$ \\
\hline $\mathrm{OH}-\mathrm{Cbl}+5-\mathrm{CHO}-\mathrm{H}_{4} \mathrm{PteGl}_{\mathrm{l}}$ & 8 & $7 \cdot 5$ & $1 \cdot 80$ & 8 & $8 \cdot 9$ & $1 \cdot 83$ \\
\hline $\mathrm{OH}-\mathrm{Cbl}+10-\mathrm{CHO}-\mathrm{H}_{4}$ PteGlu & 8 & $7 \cdot 4$ & $1 \cdot 26$ & 8 & $12 \cdot 6$ & $2 \cdot 58$ \\
\hline
\end{tabular}

Results are expressed as: $\frac{\text { counts with deoxyuridine }+\left[{ }^{3} \mathrm{H}\right] \text { thymidine }}{\text { counts with }\left[{ }^{3} \mathrm{H}\right] \text { thymidine }} \times 100$

\section{Utilisation of formate}

Lymphocytes from patients with untreated pernicious anaemia fail to synthesise serine from formate and glycine in a normal manner. These are folatedependent reactions. This was improved only after the patient had been treated with vitamin $\mathrm{B}_{12} \cdot{ }^{33} 34$ Preliminary results with marrow from $\mathrm{N}_{2} \mathrm{O}$-treated rats showed a marked impairment of this pathway.

VITAMIN B12-FOLATE INTERRELATIONS

In a review of intracellular folate metabolism given at the Annual Meeting of the American Society for Haematology in San Diego, Bertino ${ }^{35}$ stated that the methylfolate trap was no longer hypothesis, it was fact. As the few new facts that had emerged over the preceding decade had merely served to cast further uncertainty around the theory, this was a surprising statement. The absence of a satisfactory model for $\mathrm{B}_{12}$ deficiency has made it difficult to explore the 
methylfolate trap hypothesis. The effect of $\mathrm{N}_{2} \mathrm{O}$, firstly, as a means of inactivating methionine synthesis and, secondly, blocking the path by which $B_{12}$ regulates folate metabolism, has provided the first convenient opportunity for testing this hypothesis in depth.

$\mathrm{N}_{2} \mathrm{O}$ in the rat causes a transient accumulation of 5-methyltetrahydropteroylpolyglutamate, and thereafter either other pathways are induced, which brings about further metabolism of methylfolate, or its synthesis is shut off. The latter could occur if S-adenosylmethionine, which produces feedback inhibition of methylenetetrahydrofolate reductase, were shown to accumulate. This seems unlikely as synthesis of methionine virtually ceases. After this initial stage there is no further evidence of trapping of methylfolate in any tissue. There is a steady disappearance of folate from liver, rather than an accumulation in any form, and this indicates that there is no methylfolate trap.

The effect of $\mathrm{N}_{2} \mathrm{O}$ is bypassed, as far as folatepolyglutamate synthesis and deoxyuridine methylation are concerned, by the provision of formyltetrahydrofolate derivatives. Other folate analogues, and particularly unsubstituted tetrahydrofolate, were far less effective or not effective at all. Thus the role of $B_{12}$ appears to be in the formylation of tetrahydrofolate. The source of formate is serine and/or glycine, and the formation of serine from ${ }^{14} \mathrm{C}$-formate and glycine was found to be impaired in all 16 patients with $\mathbf{B}_{12}$-deficient megaloblastic anaemia studied by Tikerpae and Chanarin. ${ }^{34}$ Further elucidation of the role of $B_{12}$ is awaited.

NEUROLOGICAL EFFECTS OF N2O

The clinical observations indicating that exposure to $\mathrm{N}_{2} \mathrm{O}$ produces a neuropathy in man have been mentioned earlier in this review. Dinn et al..$^{36}$ failed to produce neurological changes in rats after eight months' exposure to $50 \% \mathrm{~N}_{2} \mathrm{O}$. However, they found that a monkey, after two months in an $\mathrm{N}_{2} \mathrm{O}$ atmosphere, became unsteady and uncoordinated with progressive ataxia, and finally the animal was unable to sit up or drink. Histological examination of the spinal cord showed degeneration of both the myelin sheath and axis cylinders in the posterior columns as well as in the lateral corticospinal and spinocerebellar tracts. In several areas of the posterior columns, entire fibre tracts were replaced by groups of fatty macrophages giving an appearance of spongy degeneration affecting also the anterior columns. The central grey matter and myelinated tracts bordering it were intact.

Biochemically methionine synthetase activity in rat brain was virtually undetectable 24 hours after $50 \% \mathrm{~N}_{2} \mathrm{O}$. It was not measured earlier than after
24 hours' exposure. There was a transient rise in the level of 5-methyltetrahydropteroylpolyglutamate as in liver, which then declined, and a fall in total folate, the decline being at a slower rate than in liver (Lumb et al., in preparation).

At the time of writing, the changes in brain are the same as the changes in other tissues, and as yet there is no evidence that $B_{12}$ neuropathy is based on interruption of different pathways from that in liver.

HAEMATOLOGICAL EFFECTS OF N2O

It should be remembered that while folate deficiency causes megaloblastic anaemia in all species, vitamin $B_{12}$ deficiency causes megaloblastic anaemia only in man. Nevertheless the biochemical sequelae of $\mathbf{B}_{12}$ lack are very similar in many species, and these include changes in the marrow of the sort measured in the deoxyuridine suppression test.

Severe neutropenia and thrombocytopenia followed the administration of $\mathrm{N}_{2} \mathrm{O}$ to man over several days, ${ }^{34}$ and in the study of Lassen et al., as in that of Amess et al., ${ }^{5}$ it is clear that haemopoiesis had become megaloblastic. In the study of Amess et al. all the patients receiving $\mathrm{N}_{2} \mathrm{O}$ for 24 hours had megaloblastic marrows. Another group received $\mathrm{N}_{2} \mathrm{O}$ only during the operation (elsewhere the time is given as less than 10 hours), ${ }^{37}$ and only three out of nine had megaloblastic haemopoiesis. One of the patients with neuropathy was noted to have hypersegmented neutrophils. ${ }^{7}$

Different strains of rat vary in their sensitivity to $\mathrm{N}_{2}$ O. 38 Sprague-Dawley rats develop leucopenia within two to three days of exposure to $50 \% \mathrm{~N}_{2} \mathrm{O}$. Male LEW/f Mai rats develop marrow hypocellularity after three days on $40 \% \mathrm{~N}_{2} \mathrm{O}$ but only after 14-21 days with $20 \% \mathrm{~N}_{2} \mathrm{O}$. There is vacuolation of myeloid precursors. Lymphopenia was an early feature. Recovery occurred three days after withdrawal of $\mathrm{N}_{2} \mathrm{O} .{ }^{39}$ After about 10 days tolerance to the effect of $40 \% \mathrm{~N}_{2} \mathrm{O}$ developed in the animals.

Human marrows collected 24 hours after $50 \%$ $\mathrm{N}_{2} \mathrm{O}$ showed an increased number of cells in the early synthetic phase (S) of DNA synthesis. ${ }^{40}$

\section{OTHER EFFECTS OF $\mathrm{N}_{2} \mathrm{O}$}

It is surprising how well rats adjust to $50 \% \mathrm{~N}_{2} \mathrm{O}$. They appear to eat normally and be as lively as normal rats. Pope et al. ${ }^{41}$ exposed Sprague-Dawley rats to 8 hours $50 \% \mathrm{~N}_{2} \mathrm{O}$ daily for the 21 -day period of gestation and did not produce fetal loss significantly different from that of a control group. There was, however, a decrease in average fetal weight (common to $\mathrm{N}_{2} \mathrm{O}$ and other anaesthetic gases such as halothane and methoxyflurane), and this was accompanied by a decrease in the numbers of ossification centres in the fetal vertebral columns. 
However, continuous exposure of pregnant rats to $\mathrm{N}_{2} \mathrm{O}(70-80 \%)$ for 24 hours on the ninth day of gestation resulted in decreased numbers of fetuses and an increase in fetal malformation..$^{42}$

\section{Conclusion}

This survey indicates that $\mathrm{N}_{2} \mathrm{O}$ is able to shut off major segments of $\mathrm{B}_{12}$ metabolism in both man and animals. Whether all the effects are through inactivation of methionine synthetase is not certain, but this seems unlikely. The nature of other pathways involved is being studied.

\section{References}

${ }^{1}$ Banks RGS, Henderson RJ, Pratt JM. Reactions of gases in solution. Part III. Some reactions of nitrous oxide with transition-metal complexes. J Chem Soc (A) 1968; 2886-9.

${ }^{2}$ Blackburn R, Kyaw M. Reaction of cob(I)alamin with nitrous oxide and cob(III)alamin. $J$ Chem Soc Faraday Transactions 1977;73:250-5.

${ }^{3}$ Lassen HCA, Henriksen E, Neukirch F, Kristensen HSK. Treatment of tetanus. Severe bone-marrow depression after prolonged nitrous-oxide anaesthesia. Lancet 1956 ; $1: 527-30$

${ }^{4}$ Wilson P, Martin FIR, Last PM. Bone-marrow depression in tetanus. Report of a fatal case. Lancet 1956;2: 442-3.

${ }^{5}$ Amess JAL, Burman JF, Rees, GM, Nancekievill DG, Mollin DL. Megaloblastic haemopoiesis in patients receiving nitrous oxide. Lancet 1978;2:339-42.

6 Layzer RB. Myeloneuropathy after prolonged exposure to nitrous oxide. Lancet 1978;2:1227-30.

' Layzer RB, Fishman RA, Schafer JA. Neuropathy following abuse of nitrous oxide. Neurology 1978;28: 504-6.

${ }^{8}$ Sahenk Z, Mendell JR, Couri D, Nachtman J. Polyneuropathy from inhalation of $\mathrm{N}_{2} \mathrm{O}$ cartridges through a whipped-cream dispenser. Neurology 1978;28:485-7.

- Gutman L, Farrell B, Crosby TW, Johnson D. Nitrous oxide-induced myelopathy-neuropathy: potential for chronic misuse by dentists. J Am Dent Assoc 1979;98:58-9.

${ }^{10}$ Cohen EN, Brown BW, Wu M. Anesthetic health hazards in the dental operatory. Anesthesiology 1979;51:5254 (Abstract).

${ }^{11}$ Chanarin I. The Megaloblastic Anaemias. 2nd ed. Oxford: Blackwell, 1979.

${ }^{12}$ Smith RM, Osborne-White WS. Folic acid metabolism in vitamin $B_{12}$-deficient sheep. Depletion of liver folates. Biochem J 1973;136:279-93.

${ }^{13}$ Smith RM, Osborne-White WS, Gawthorne JM. Folic acid metabolism in vitamin $\mathrm{B}_{12}$-deficient sheep. Biochem $J$ 1974;142:105-17.

${ }^{14}$ Green R, van Tonder SV, Oettle GJ, Cole G, Metz J. Neurological changes in fruit bats deficient in vitamin $B_{12}$. Nature 1975;254:148-50.

${ }^{15}$ Deacon R, Lumb M, Perry J, Chanarin I, Minty B, Halsey MJ, Nunn JF. Selective inactivation of vitamin $B_{12}$ in rats by nitrous oxide. Lancet $1978 ; 2: 1023-4$.

16 Deacon R, Lumb M, Perry J, Chanarin I, Minty B, Halsey MJ, Nunn JF. Inactivation of methionine synthase by nitrous oxide. Eur J Biochem 1980;104:419-422.

17 Deacon R, Chanarin I, Perry J, Lumb M. Impaired deoxyuridine utilization in the $\mathrm{B}_{12}$-inactivated rat and its correction by folate analogues. Biochemical and Biophysical Research Communications 1980;93:516-520.

${ }^{18}$ Kondo H, Osborne M, Podell E, Kolhouse JF, Allen RH. Nitrous oxide $\left(\mathrm{N}_{2} \mathrm{O}\right)$ has multiple effects on cobalamin (CBL) metabolism. Blood 1979;54: Supplement 1;41a.

19 Scott JM, Reed B, McKenna B, McGing P, McCann S, O'Sullivan H, Wilson P, Weir DG. A study of the multiple changes induced in vivo in experimental animals by inactivation vitamin $B_{12}$ using nitrous oxide. In: Kisliuk RL, Brown GM, eds. Chemistry and Biology of Pteridines. NY: Elsevier, 1979;335-40.

${ }^{20}$ Linnell JC, Quadros EV, Matthews DM, Jackson B, Hoff brand AV. Nitrous oxide and megaloblastosis: biochemical mechanism. Lancet 1978;2:1372.

${ }^{21}$ Schrauzer GN, Stadlbauer EA. Ethanolamine ammonialyase: Inactivation of the holoenzyme by $\mathrm{N}_{2} \mathrm{O}$ and the mechanism of action of coenzyme $\mathrm{B}_{12}$. Bioinorg Chem $1975 ; 4: 185-98$.

${ }^{22}$ McGing P, Reed B, Weir DG, Scott JM. The effect of vitamin $\mathrm{B}_{12}$ inhibition in vivo: impaired folate polyglutamate biosynthesis indicating that 5 -methyltetrahydropteroylglutamate is not its usual substrate. Biochem Biophys Res Commun 1978;82:540-6.

${ }^{23}$ Perry J, Chanarin I, Deacon R, Lumb M. The substrate for folate polyglutamate biosynthesis in the vitamin $B_{12}$ inactivated rat. Biochem Biophys Res Commun 1979;91: 678-84.

${ }^{24}$ Herbert $\mathrm{V}$, Zalusky $\mathrm{R}$. Interrelation of vitamin $\mathrm{B}_{12}$ and folic acid metabolism: folic acid clearance studies. $J$ Clin Invest 1962;41:1263-76.

${ }^{25}$ Noronha JM, Silverman M. On folic acid, vitamin $B_{12}$, methionine and formiminoglutamic acid metabolism. In: Heinrich HC, ed. Vitamin $B_{12}$ und Intrinsic Factor. 2. Europäisches Symposion. Stuttgart: Enke, 1962;728-36.

${ }^{26}$ Lumb M, Deacon R, Perry J, Chanarin I, Minty B, Halsey MJ, Nunn JF. The effect of nitrous oxide inactivation of vitamin $B_{12}$ on rat hepatic folate. Implications for the methylfolate-trap hypothesis. Biochem $J$ 1980;186:933-6.

27 Pearson AGM, Turner AJ. Folate dependent 1-carbon transfer to biogenic amines mediated by methylenetetrahydrofolate reductase. Nature 1975;258:173-4.

${ }^{28}$ Stebbins RD, Meller E, Rosengarten H, Friedhoff A, Silber R. Identification of $\mathrm{N}^{5}, \mathrm{~N}^{10}$-methylenetetrahydrofolate reductase as the enzyme involved in the 5-methyltetrahydrofolate-dependent formation of a $\beta$-carboline derivative of 5-hydroxytoyptamine in human platelets. Arch Biochem Biophys 1976;173:673-9.

29 Taylor RT, Hanna ML. 5-Methyltetrahydrofolate aromatic alkylamine $N$-methyltransferase: an artefact of 5,10-methylenetetrahydrofolate reductase activity. Life Sci 1975;17:111-20.

${ }^{30} \mathrm{Killman}$ S-A. Effect of deoxyuridine on incorporation of tritiated thymidine: difference between normoblasts and megaloblasts. Acta Med Scand 1964;175:483-8.

${ }^{31}$ Metz J, Kelly A, Swett VC, Waxman S, Herbert V. Deranged DNA synthesis by bone marrow from vitamin $B_{12}$-deficient humans. Br J Haematol 1968;14:575-92.

${ }^{32}$ Goodman A, Pinchak A, Harris JW. In vitro effects of nitrous oxide. Blood 1979;54: Suppl 1;38a (Abstract).

${ }^{33}$ Ellegaard J, Esmann V. Folate deficiency in pernicious anaemia measured by determination of decreased serine synthesis in lymphocytes. $\mathrm{Br} J$ Haematol $1973 ; 24: 571-7$.

34 Tikerpae J, Chanarin I. Folate-dependent serine synthesis in lymphocytes from controls and patients with megaloblastic anaemia: The effect of therapy. Br J Haematol $1978 ; 38: 353-8$.

${ }^{35}$ Bertino J. Intracellular folate metabolism. Blood 1977;50: Supplement 1, 38. 
${ }^{36}$ Dinn JJ, McCann S, Wilson P, Reed B, Weir D, Scott J. Animal model for subacute combined degeneration. Lancet 1978;ii 1154.

${ }^{37}$ Amess JAL, Burman JF, Greany M, Nancekievill DG. The effect of nitrous oxide on haematopoiesis. In: Proceedings of 4th Meeting of European and African Division of the International Society of Haematology, Istanbul. 1977; Abstract 614.

${ }^{38}$ Green CD, Eastwood DW. Effects of nitrous oxide inhalation on hemopoiesis in rats. Anesthesiology 1963; 24:341-5.

${ }^{39}$ Kripke BJ, Talarico L, Shah NK, Kelman AD. Hematologic reaction to prolonged exposure to nitrous oxide Anesthesiology 1977;47:342-8.

40 Cullen MH, Rees GM, Nancekievill DG, Amess JAL. The effect of nitrous oxide on the cell cycle in human bone marrow. Br J Haematol 1979;42:527-34.

41 Pope WDB, Halsey MJ, Lansdown ABG, Simmonds A, Bateman PE. Fetotoxicity in rats following chronic exposure to halothane, nitrous oxide, or methoxyflurane. Anesthesiology 1978;48:11-6.

${ }^{42}$ Shepard TH, Fink BR. In:Fink BR, ed. Teratogenic Activity of Nitrous Oxide in Rats, Toxicity of Anesthetics. Baltimore: Williams and Wilkins, 1968;308-23.

${ }^{43}$ Lane GA, Nahrwold ML, Tait AR, Taylor BS, Beaudoin AR, Cohen PJ. Nitrous oxide is teratogenic: xenon is not! Anesthesiology 1979;51:S260 (Abstract).

Requests for reprints to: Dr I Chanarin, Northwick Park Hospital, Watford Road, Harrow, Middlesex HA1 3UJ, UK. 